\title{
Suomen kiuas, karjalan kiukua ja havaintoja etymologian tutkimusperinteestä
}

FINAL DRAFT OF 11 JUNE 2016

Jussi Ylikoski

\section{Aluksi}

Tämä kirjoitus tarjoaa katsauksen suomen kielen kiuasta merkitsevien sanojen ja niiden karjalassa tavattavien vastineiden alkuperään ja sen tutkimukseen (jakso 2). Tarkastelun aloittaa vilkaisu pohjoiseurooppalaisten saunojen kiukaiden alkuperään ja nimityksiin (jakso 2.1). Katsausta suomen kiukaan ja karjalan kiukuan alkuperän tutkimushistoriaan (jakso 2.2) seuraa analyysi, jossa verrattavina ovat etenkin kiukaan etymologiseksi selitykseksi vakiintunut yhdyssana *kivikota sekä parin aivan lyhyen, irrallisen ja perustelemattoman huomautuksen varaan jäänyt ajatus, jonka mukaan sanan alkumuoto olisi pikemminkin *kivikasa. Niin näiden vaihtoehtojen äännehistoriallinen ja murremaantieteellinen tarkastelu (jakso 2.3) kuin merkitysopillisetkin seikat (jakso 2.4) puhuvat vahvasti jälkimmäisen, aiemmin lähes huomiotta jääneen selityksen puolesta: Suomessa puhutaan kiukaasta tai muun muassa kiukahasta, koska nykysuomea edeltävien kielimuotojen puhujat näyttävät puhuneen *kiukasasta ja sitä ennen *kivikasasta. Kirjoituksen päättää kokoava pohdiskelu (jakso 3) kiukaan alkuperän tutkimuksen historiasta ja periaatteista sekä laajemmin kiukaan kaltaisten hämärtyneiksi yhdyssanoiksi tulkittavien sanojen etymologisoinnin haasteista ja mahdollisuuksista. Vaikka yhdyssanojen hämärtyminen sinänsä on luonnollinen osa kielen elämää, kyse on samalla epäsäännöllisistä yksittäistapauksista, joiden ymmärtäminen vaatii varovaisia askeleita historiallis-vertailevan kielitieteen perusvaatimuksiin kuuluvien säännöllisten äänne- ja muotovastaavuuksien ulkopuolelle.

\section{Kiukaan alkuperä}

\subsection{Kiuas ja kiukaan alkuperä}

Suomen kiuas on Kielitoimiston sanakirjan määritelmän mukaan 'saunan (ennen myös riihen t. savupirtin) tav. uunimainen lämmitin, jonka yläosassa on lämpöä varastoiva kiviladelma'. Saunoja ja saunanomaisia kylpemisrakennuksia tunnetaan eri puolilta pohjoista pallonpuoliskoa, ja itämerensuomalaiset saunat edustavat pohjoiseurooppalaisen metsävyöhykkeen suomalaisugrilaisille kansoille (myös mordvalaisille ja mareille sekä permiläisille komeille ja udmurteille) ja 
heidän lähimmille slaavilaisille, balttilaisille, skandinaavisille ja turkkilaisille naapureilleen kuulunutta kansankulttuuria. Alkukantaisimpana kiuastyyppinä pidetään maakivistä ladottua pyöreäkupuista ja sisäänsavuavaa avokiuasta, niin sanottua rauniokiuasta; tällaisia on yhä käytössä monissa savusaunoissa ja ne vaikuttavat olleen vallitseva kiuas- ja saunatyyppi keskirautakaudelta 1800-luvulle asti. Saunomisen ja kiukaan alkuperää ja kehitystä ovat tarkemmin kuvanneet muun muassa Helamaa (1999; 2000) ja Pentikäinen (1999). Koska rakennustekniikan myöhemmän kehityksen yksityiskohdat ovat kiuas-sanan alkuperää selviteltäessä vähemmän oleellisia, tässä artikkelissa lähtökohtana ovat suomen ja karjalan nykyisten puhuma-alojen kehittyessä vallalla olleet rauniokiukaat (kuva 1).

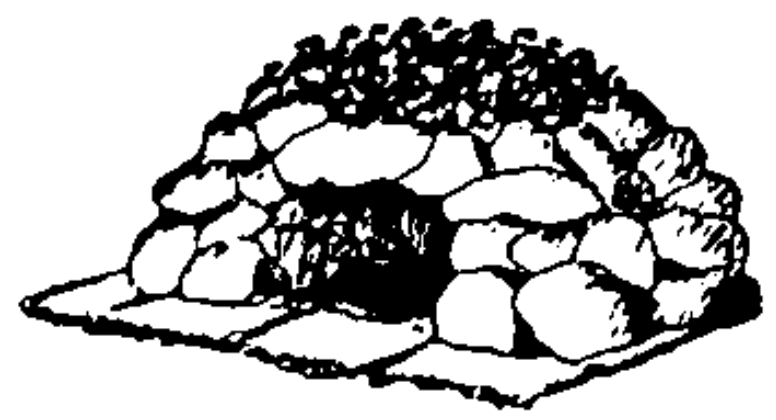

Kuva 1. Alkukantaiselle savupirtille ja saunalle ominainen avo- eli rauniokiuas Helamaan (1999, 119) mukaan.

Saunan ja siihen liittyvän sanaston etymologia on kiehtonut lukuisia tutkijoita ja maallikoita sekä Suomessa että sen ulkopuolella (esim. Vilkuna 1972, Kallio 2008, Tsypanov 2013).

Itämerensuomen sauna on pitkään yhdistetty mm. pohjoissaamen sanaan suovdnji 'lumeen kaivettu kuoppa; riekonkieppi' ja löyly esimerkiksi pohjoissaamen sanaan lievla 'höyry, löyly; tuoksu' ja unkarin sanaan lélek 'sielu; henki' (SSA). Suomalais-karjalaisen kiukaan ja alempana puheeksi tulevien lyydin ja vepsän sanojen vastineita ovat muun muassa viron erilähtöinen keris variantteineen sekä suomalaisen saunakulttuurin ilmeisestä vaikutuksesta pohjoissaameen lainattu givggis givgás ja inarinsaamen kivkkâhâš.

Aunuksen kannaksen laajalla karjalais-livviläis-lyydiläisellä alueella kiukaan nimityksenä on venäjästä lainattu (külün/rihen) päčči (ALFE 1: 170, 172). Venäjän peč' tosin merkitsee lähinnä uunia, kun taas kamenka 'kiuas' (myös homonyymi 'kivitasku') pohjautuu kiveä merkitsevään sanaan kamen'. Venäjän kamenka näkyy jo aikaa sitten lainatun ersään muodossa kaminka ilmaisun bańa-ḱev́t "saunakivet" rinnalle (MW s.v. ḱev). Mokšasta on kirjattu muistiin (pańäń) ḱev-mar ja pańä-ḱev-mar"(saunan) kivikasa" (MW s.v. kev, mar). Myös marissa ja udmurtissa puhutaan saunan kivistä; marin mońća kü ja udmurtin munćo iz pohjautuvat turkkilaiskielistä lainattuihin 
saunaa merkitseviin sanoihin. Komin pivvśan gor tarkoittaa sananmukaisesti saunan uunia. Erityisesti kiuasta merkitsevät opaakit, yhdistämättömät substantiivit kuuluvat siis lähinnä itämerensuomalaisiin kieliin. Kartta 1 osoittaa kiuasta merkitsevien sanojen äänneasut ja levikit itämerensuomalaisen kielikartaston (ALFE) kuvaamana.

\section{[KARTTA 1 SUUNNILLEEN TÄHÄN]}

Kartta 1. Itämerensuomen kiuasta merkitseviä sanoja ALFEn (1: 171) mukaan.

\subsection{Kiukaan alkuperän tutkimuksesta}

Merkitykseltään varsin konkreettisen kiuas-substantiivin alkuperä vaikuttaa pysyneen tähän asti erikoisen hämäränä. Koska kiukaat ladotaan aina kivistä, sanan alkuosa tosin on Ahlqvistista (1866, 110) alkaen yhdistetty ikivanhaan kivi-sanaan, mutta loppuosan tulkinnat ovat vaihdelleet. Yleisimmin esitetyn käsityksen mukaan kiuas on hämärtynyt yhdyssana, jonka loppuosan taustalla on niin ikään muinainen kota. Selityksen *kivikota > kiuas esittää ensimmäisenä Sirelius (1907, 128). Ensisijaisesti tai jopa yksinomaisesti tähän viittaavat yksissä tuumin niin etymologiset sanakirjat SKES, SSA ja NSES (s.v.) kuin kielikartasto ALFE (1: 172). Tätä äänteellisesti yllättävää

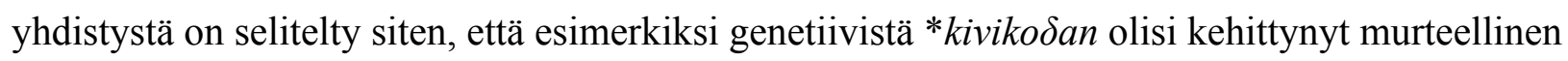

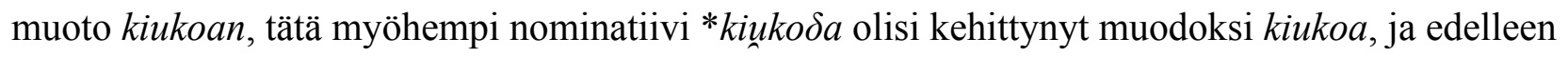
nykyinen nominatiivi kiuas selittyisi myöhemmäksi analogiamuodosteeksi (SSA). Kettunen (1922, 17, 46) puolestaan selittää vepsän samaa merkitsevän kiudug kivdug -sanan (nykykirjakielen küudug) sanojen kivi ja "tukka" (tuk 'läjä, kasa') yhdistymäksi. SKES (s.v. kiuas) mainitsee vepsän sanan ja lyydin kiudug-muodon sekä yhdistää ne suomen kiuas-sanaan, mutta jättää Kettusen selityksen huomiotta. Samoin tekee SSA, joka mainitsee Kettusen vain kirjallisuusviitteessä yhdessä Lindgrenin (1982, 199-203) germaanisen lainaehdotuksen kanssa. Lindgren yhdistää sanan germaaniseen vartaloon * $\chi a u \gamma a-$, jonka perillisiä on mm. ruotsin kasaa merkitsevä hög. Kyseiseen, jo alkuaan hyvin varovasti ehdotettuun sanayhdistykseen on kuitenkin äännehistoriallisista syistä suhtauduttu yksimielisen torjuvasti (ks. SSA, LÄGLOS, NSES; Itkonen 1983, 124-125; Ritter 1993, 163-165).

Viimeisin suomen kielen etymologinen sanakirja, Häkkisen (2004) Nykysuomen etymologinen sanakirja (NSES) tekee kuitenkin kiuas-sanan etymologian kuvaukseen kiinnostavan lisäyksen mainitsemalla vepsän ja lyydin sanojen yhteydessä, että "myös suomen sanaa kiuas tai kiukas on vastaavasti arveltu yhdyssanaksi *kivikasa”. NSES ja siinä mainitut viitteet eivät spesifioi tällaisen 
arvelun esittäjää, mutta sellainen on löydettävissä yhdestä tai kahdesta, mahdollisesti toisistaan riippumattomasta lähteestä. Ensi kerran ja selvimmin tämä näkyy mainitun Lindforsin (1893: 14) Heinolan ja sen lähiseutujen murretta esittelevässä tutkimuksessa. Havainnollistaessaan loppuheiton aiheuttamaa $v$ :n vokaaliutumista Lindfors lisää esimerkkiensä kiu 'kivi', sau 'savi' ja käyn 'kävin' yhteyteen seuraavan pienen alaviitteen: "Kiuas = kivikasa? Vrt. A. Ahlqvist, Suomen kielen rakennus, § 127, *).” Lindforsin viittaus Ahlqvistiin $(1877,73)$ osoittaa tämän oletukseen, että esimerkiksi sanan rahakas johdin -kas olisi syntynyt kasa-sanasta, mutta Ahlqvistin käsitys on syytä ohittaa oman aikansa tuotteena. Lindforsin ehdotukseen ei ole tiettävästi koskaan viitattu.

*Kivikasa-selitystä muistuttavat ajatukset näyttävät nousevan esiin seuraavan kerran vasta sata vuotta Lindforsin (1893) jälkeen, kun itämerensuomen vanhimpia germaanilainoja käsitellessään Ritter (1993, 163-165) torjuu yllä mainitun Lindgrenin (1982) germaanisen lainaehdotuksen. Tässä yhteydessä hän toteaa (mts. 165) SKES:n esittämän *kivikota : *kivikoan -etymologian sopivan sanan kaikkiin edustumiin. Lingrenin esitystä edelleen kritisoivan alaviitteensä 81 lopuksi Ritter kuitenkin yllättäen tokaisee Lindgrenille tärkeän kiukaa-allomorfin puuttuvan niin kantasuomesta kuin suomen kirjakielen pohjana toimineiden murteiden ulkopuolelta: "schriftfi. kiukaa- ist aus kiukaha- (<*kiukasa-) entstanden”. Lähdeviitteitä Lindforsiin (1893) tai muualle tai ylipäänsä muita dialektologisia argumentteja Ritter ei otaksumansa tueksi esitä, joten tämäkin lause jää lähinnä tutkimushistorialliseksi kuriositeetiksi. Tarkalleen ottaen Ritter ei edes viittaa sanaan kasa tai esitä kantamuotoa *kivikasa eikä mainitsemansa kantamuodon *kiukasa- alkuperäisempää merkitystä. Germaanilainasanakirja LÄGLOS (1996 s.v. kiuas) huomioi kyllä Ritterin (1993) kirjallisuusviitteenä, mutta muuten tyytyy mainitsemaan vain *kivikota-selityksen sekä toteamaan Lindgrenin lainaetymologian muoto- ja merkitysperusteiltaan heikoksi.

Vielä yhtenä kiuas-sanan endogeenisenä selityksenä on viitattu (Häkkinen 1990, 158; SSA s.v.) Rapolan $(1933,151 ; 1966,133)$ vaillinaisesti perustelemaan esitykseen, jonka mukaan tähän "[k]ulttuurihistoriallisesti kovin tärkeään sanaan enemmälti syventymättä voitaneen kuitenkin

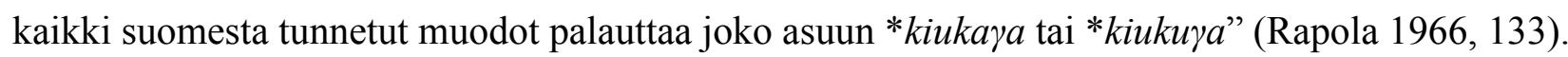
Tämä ajatus näyttää juontavan juurensa myöhemmissä etymologisissa kuvauksissa unohtuneeseen,

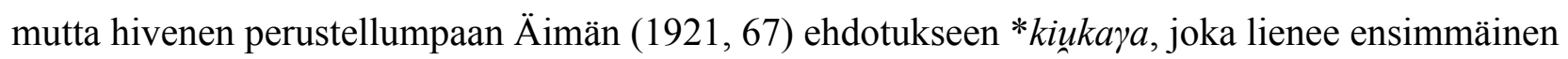
yritys suomen kiuas- ja vepsän küudug-sanojen yhdistämiseksi.

Yhdyssanaan *kivikasa pohjautuvien selitysten minimalistisuudesta huolimatta vaikuttaa siltä, että juuri tämä etymologia selittää suomen kiuas-sanan mitä moitteettomimmin. Ensinnäkin on huomattava, että kiukaalla on itämerensuomessa lukuisia nimityksiä, joista kiuas variantteineen on 
nimenomaan pääasiassa suomalainen sana. SSA:ssa mainitaan suomen, lyydin ja vepsän lisäksi inkeroisen kiukā 'uuni, kiuas' ja karjalan kiukoa '(saunan) kiuas, (tuvan) uuni'. Vienankarjalan nykykirjakielessä sana on muotoa kiukua. Inkeroisen ja suomen leksikaalinen läheisyys on tunnettua, ja karjalan sana tunnetaan vain vienan- ja tverinkarjalasta sekä Salmin livvistä (KKS s.v.; ALFE 1: 170-171); lisäksi ALFE (mp.) mainitsee länsivatjan sanan tšiukas, Kukkosin kiugas. Oleellista on, että küudug variantteineen esiintyy lähinnä vain vepsässä, sillä lyydiläinen kiudug tunnetaan vain Kontupohjan Kortašin kylästä. Vaikka koko muu varsinaiskarjalainen, livviläinen ja lyydiläinen alue puhuu kiukuan tai küudugan sijaan pätsistä (ALFE 1: 170), etenkin Räsänen (1947, 354-355) näkee paljon vaivaa yhdistääkseen nämä kaksi maantieteellisestikin etäistä sanaa toisiinsa erilaisten sisä- ja loppuheittojen, analogioiden, metateesien ja sporadisten vokaalimuutosten kautta. Aunuksen kannaksen karjalais-livviläis-lyydiläisellä alueella kiukaan nimityksenä on siis venäjästä lainattu (külün/rihen) päčči (ALFE 1: 170, 172). Viron kiuasta merkitsevä keris variantteineen sekä liivin kerīkš on selitetty alkuperältään balttilaisiksi ja ne jäävät näin ollen tämän artikkelin aiheen ulkopuolelle (esim. ALFE mp.; EES s.v.). Suomen murteissa kiukaalla on myös levikiltään suppeampia merkityksiä 'lämpöä varastoiva ja löylyä antava (mukula)kivikerros', 'tuvan uuni', 'leivinuuni' ja 'uunin päällys, pankko' (SMS s.v.).

\section{3. Äännehistoriallista ja murremaantieteellistä uudelleenarviointia}

Suomalais-karjalaisen sanueen kiuas $\sim$ kiukaa $\sim$ kiukoa $\sim$ kiukua ja lyydiläis-vepsäläisten sanojen kiudug $\sim$ küudug erillisyyden tunnustaminen ja niiden eri varianttien maantieteellinen tarkastelu osoittavat melko yksiselitteisesti, että molemmat sanat ovat kehittyneet suunnilleen 'kivikasa'merkityksisistä yhdyssanoista. Vepsäläis-lyydiläinen kiudug küudug onkin kaiketi juuri Kettusen (1922, 17, 46) olettamaan tapaan yhdyssana kivi + "tukka". LMS:n (s.v.) mukaan lyydissä on erotettavissa kaksi tuk-sanaa - pääasiallisesti $a$-vartaloinen 'hius' ja $u$-vartaloinen 'kasa, läjä' - ja SVJa listaa tuk-sanalle monia nippuihin, kimppuihin ja tukkoihin viittaavia merkityksiä. Suomalaiskarjalainen kiuas variantteineen puolestaan vaikuttaa olevan samanlainen kiteytymä yhdyssanasta *kivikasa - alkuperältään germaaniseksi tai skandinaaviseksi katsotun kasa-sanan levikki rajoittuukin lähinnä suomeen (SSA s.v.; LÄGLOS s.v.).

Tarkemmin katsottuna *kivikasa päihittää klassisen *kivikota-selityksen sekä äänneasun että merkityksen perusteella. *Kivikota-selitys sisältää siis ajatuksen varhaisesta kiukoa-vartalosta, jonka pohjalta olisi myöhemmin abstrahoitu vartalo kiukaa- ja toisaalta nominatiivimuoto kiuas. Vartalon kiukoa- reanalysointi muotoon kiukaa- vaatisi kuitenkin jälkitavujen -oa- - $a a$ - -vokaalien alueellisen vaihtelun huomioivan rajapinnan eli se voitaisiin sijoittaa aikaisintaan lähinnä suomen 
itämurteiden alueella (eteläisiä kaakkoismurteita ja Etelä-Pohjanmaan savolaiskiilaa lukuun ottamatta; Kettunen 1940, kartta 179; ks. myös Rapola 1966, 411-413) tapahtuneiden -aa- > -oa- > -oo- muutosten aikaan (ja paikkaan). Kyseisiä muutoksia on pidettävä verrattain myöhäisinä ja näin ollen tuntuu suorastaan mahdottomalta, että vartalo kiukaa- olisi reanalysoitu - kautta koko suomen puhuma-alueen - vasta tässä vaiheessa; tällainen muutoshan vaatisi mallikseen analogian tyyppiä kal(l)oa (itämurteet) : kal(l)aa (länsimurteet) = kiukoa- (itämurteet) : X (länsimurteet); X = kiukaa-. Hypoteesin huipennukseksi olisi nähtävästi oletettava, että vasta tällaisen muutoksen jälkeen olisi syntynyt sittemmin lähes kaikkialla tunnettu nominatiivi kiuas. ${ }^{1}$

Kaiken kaikkiaan on todettava, että *kivikota-oletusta ei voi uskottavasti perustella käytännössä minkäänlaisin itämerensuomen tunnettuun äännehistoriaan perustuvin argumentein. Vaihtoehtoisen *kivikasa-yhdyssanaan perustuvan etymologian voi sen sijaan perustella lyhykäisyydessään viittaamalla pariin keskeiseen ja vanhastaan tunnettuun äänteenmuutokseen sekä kiuas-sanan eri varianttien levikkiin ALFEn ja SMS:n paljastamana. Oletetun yhdyssanan kiteytymistä opaakiksi lekseemiksi kiuas : kiukaa- on tietysti sinänsä pidettävä arvaamattomana leksikaalistumisena; odotuksenmukaisinta olisi, että löylyvettä heitettäisiin nykyäänkin pelkälle kivikasalle. Sanan tutkimushistoriasta kuitenkin nähdään, että muutosta *kivi- > kiv-/kiu- ei ole pidetty erityisen ongelmallisena, ja sanan loppuosa - $a s:-a(h) a$--vaihteluineen rinnastuu lukuisiin vartalotyyppeihin (esim. sairas : saira(h)a-ja johdostyyppi rahakas : rahakka(h)a-). Alkuperäisempänä on helppo pitää *kiv(i)kasa-vartaloa, jonka loppuvokaali nominatiivissa - ja analogisesti myöhemmin partitiivissakin - on heittynyt. Muissa taivutusmuodoissa jälkitavujen vokaalien välinen - $s$ - on normaalin suffiksaalisen astevaihtelun tapaan muuttunut $h$ :ksi ja useimmissa murteissa edelleen kadonnut. Fonotaktisesti sopimattoman *-vk-yhtymän puolivokaali on luonnollisesti vokaaliutunut substantiivin kiu tapaan ja vokaalienvälinen -k- sopeutunut astevaihteluun. Kehitystä *kivikasa : *kivikasan >> kiu(k)as : kiuka(h)an eri vaiheineen voi siis pitää lähes säännönmukaisena sen jälkeen, kun yhdyssana on poikkeuksellisesti kiteytynyt yhdeksi sanaksi, nominatiivissa mahdollisesti muotoon *kiukas(a). Alkuperäiseen jälkiosaan *kasa näyttää vielä viittaavan myös vatjan tšiukas- ja kiugas- sekä Perhon, Vetelin ja Kaustisen ja samoin Taipalsaaren kiukasnominatiiveissa (ALFE; SMS) nähtävä klusiili. Kenties myös pohjoissaamen givgás-lainan asu voi palautua alkuperäisemmän muodon säilyttäneeseen lainanantajatahoon.

\footnotetext{
${ }^{1}$ On suorastaan yllättävää, että Lindgrenin (1982) germaanista lainaetymologiaa ruotiessaan Terho Itkonen (1983, 124) asettuu puolustamaan perinteistä käsitystä esittäen, että sanan (kiuas, kiukaa, kiukoa, kiukoo, kiukua, kiukuva jne.) jälkitavujen vokaalisto on *kivikota-selityksen kannalta ”täysin odotuksenmukainen kaikissa muinaiskarjalan perillisissä”. Toisaalta hänkin joutuu toteamaan (mas. 125), että oletetun *kivikota-alkumuodon kehittyminen niinkin erilaisiin muotoihin kuin kiuas ja kiudug on seurausta siitä, että sanojen "kehitys on tempautunut eri suuntiin".
} 
Mitä kiuas-sanan muihin nominatiivimuotoihin tulee, *kivikota-selityksen tueksi esitetty kiukoa ja muut samantyyppiset muodot on ALFEn (1:171) kartan avulla helppo nähdä aivan toisessa valossa (ks. myös SMS s.v. kiuas). Alkuperäisimmin *kivikasa-muodosta periytyvästä kiuas-nominatiivista on yhä jälkiä Inkeriä lukuun ottamatta kaikilta suomen murrealueilta, mutta sen rinnalla on havaittavissa selvästi itämurteinen obliikvisijojen kiuka(h)a-vartaloon pohjautuva uudennostyyppi, jonka ytimessä on levikiltään pohjoissavolainen kiukoo, jota ympäröi etelässä (lähinnä EteläSavossa ja Keski-Suomessa) ja pohjoisessa (Kainuussa) kiukoa, ja hieman kauempana (Etelä-Savon eteläosissa, Kymenlaaksossa ja Karjalan kannaksella sekä toisaalta Kainuun takaisessa Vienassa) kiuku(v)a. Laajimmin suomen itämurteissa esiintyy - kiuas-muodon ohella Inkeristä aina Kainuuseen ja Etelä-Pohjanmaan savolaiskiilaan asti - kiukaa (Inkerissä myös kiukkaa). Marginaalisempia ovat suppea-alaisemmin päämurteiden rajaseuduille rajoittuvat kymenlaaksolainen kiukaja sekä keskikarjalainen kiukuu.

Nämä levikit käyvät varsin selvästi yhteen monien muiden jälkitavuihin kehittyneiden - $a a-$ vokaalien kokemien muutosten kanssa. Esimerkiksi Kettusen (1940) kalaa-partitiivin muotoja kuvaava kartta 179 osoittaa, kuinka *kala $\delta a$-muodosta savolaismurteiden ydinalueella kehittyneen kalloo-muodon alue kattaa ALFEn kiukoo-muodon alueen, kun taas savolaismurteiden ydinalueen reunoja yhdistää kal(l)oa ja kiukoa; edelleen jopa marginaalisemmilla kal(l)ua- ja kiuku(v)amuodoilla on nähtävissä yhtymäkohtia (vrt. myös Rapola 1966, 411-413). Vaikeammin selitettävissä on kuitenkin se, että vokaalienvälisen pääpainottoman $h: n$ katoa seurannut pitkä $a a$ on normaalisti diftongoitunut vain kaakkoismurteissa (esim. lampahan >>lampoan), kun taas savolaismurteissa diftongoituminen näyttää edeltäneen $h$ :n katoa $($ kal(l)oa $\sim$ kalloo, mutta lamp(p)aan) ja myös kiukoa-muodot ovat näin ollen erityisen odotuksenmukaisia vain kaakkoismurteissa (ks. Rapola mts. 412). On kuitenkin huomionarvoista, että lekseemin kiuas uudet vokaalivartaloiset nominatiivimuodot ovat kaikkiaankin paljon sporadisempia ja vakiintumattomampia kuin jälkitavujen $V(h) V$-sekvenssien kokemat muutokset yleensä. Alkuperäisemmäksi oletettava nominatiivi kiuas on säilynyt suomessa joka puolella Inkeriä lukuun ottamatta ja vokaalivartaloisista muodoista odotuksenmukaisin, kiukaa, esiintyy siis laajasti kautta savolaismurteiden niilläkin seuduin, joista tunnetaan myös edelleen kehittyneitä kiukoa- ja kiukoomuotoja.

Katsottiinpa ALFEn (1: 171; eri varianttien levikeistä ks. myös SMS s.v. kiuas; KKS s.v. kiukoa) kuvaamaa variaatiota minkä etymologisen selityksen näkökulmasta hyvänsä, eri varianttien kirjoa etenkin savolaismurteiden alueella on pidettävä hämmentävän monipuolisena; esimerkiksi Juvalla 
kuvataan tavatun niinkin monta muotoa kuin yleissuomalainen kiuas, yleisitämurteinen kiukaa, pohjoissavolainen kiukoo, eteläisempi kiukoa sekä Kymenlaaksossakin tunnettu kiuku(v)a. Variaation voinee luontevimmin selittää siten, että tämän alkuaankin epäodotuksenmukaisesti yhdyssanan olemuksensa kadottaneen sanan äännekehitys on kulkenut nopeammin ja kenties useammassakin aallossa kuin yleisempien taivutusmuotojen ja -ryhmien $*_{-s-}>*_{-} h->_{-} \varnothing--$ kehitys.

Karjalan yksinomainen, rinnakkaista kiuas-tyyppiä vailla oleva kiuku(v)a kiugua näyttää viittaavan siihen, että *kivikasa on itäisimmillä alueillaan kehittynyt vokaalivartaloiseen muotoon myös nominatiivissa jo kauan sitten, ehkä jo alkuaankin. Toisaalta juuri karjalan muotojen odottaisi säilyttäneen jälkitavujen vokaalien välisen $-h$-:n yhtä hyvin kuin se on eteläpohjalaismurteiden kiukaha-obliikvivartalossa säilynyt. Kun samalla muistetaan, että karjalan sana tunnetaan vain vienan- ja tverinkarjalasta sekä Salmin livvistä, yksinkertaisin selitys lienee pitää sanaa lainana lännestä - sanahan on kehittynyt pohjoiseen itämerensuomeen kauan ennen nykyisten kielirajojen syntyä. Samantyyppinen, joskin hivenen laajempi levikki on suomalaisella saunalla, joka tunnetaan karjalan läntisimmissä kielimuodoissa yleiskarjalaisen külün rinnalla (KKS s.v. kyly, sauna; ALFE 1: 168-169). Lainanantomuodon vokalismista (esimerkiksi Kuhmon ja Suomussalmen kiukaa kiukoa) riippumatta on odotuksenmukaista, että karjalan äännejärjestelmään sopeutuessaan sanasta on tullut kiukua variantteineen (vrt. piirua 'piirakka', suappua 'saapas'). Suomen savolaismurteiden muotojen poikkeuksellisen variaation synty voidaan kai luontevimmin tulkita samaan tapaan kuin itämurteiden kehitys yleensäkin - lännen hämäläisen ja idän karjalaisen kielimuodon risteymäksi.

\subsection{Semanttista uudelleenarviointia}

Myös kiuas-sanan ja sen alkuperäksi tarjoutuvan *kivikasa-yhdyssanan semanttinen yhteys on niin luonnollinen, että asia ei juurikaan kaipaisi selityksiä, jollaisia paljon ongelmallisemmaksi katsomani *kivikota-etymologian yhteydessä sitä vastoin ei ole edes yritetty esittää. Kiukaiden ja muiden kivikasojen semanttinen yhteys on lähtökohtana - Kettusen (1922) kiudug < * "kivitukka" -

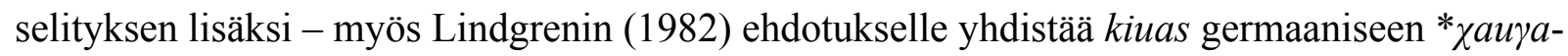
vartaloon. Edellä todettiin tähän etymologiaan suhtaudutun yksiselitteisen torjuvasti, mutta syyt ovat olleet erityisesti äänteellisiä. Lindgren pitää kiukaan ja kasan semanttista yhteyttä lähes itsestäänselvyytenä (mas. 199-201), ja juuri kivikasaan perustuvan selityksen tueksi tarjoutuvat myös samaa merkitsevät vepsän küudug ja mokšan kevmar (кевмар). Osittaista lisätukea *kivikasaselitykselle näyttäisi tarjoavan myös Kallion (2008) sauna-sanalle esittämä selitys, jonka mukaan kantasuomen *sakna on yhdistettävissä paleogermaanin vartaloon *stag ${ }^{h}$-ná-, josta kehittyi kantagermaanin *stakka- ja edelleen mm. englannin stack 'kasa'. Niin Kallio (mas. 315) kuin jo 
Lindgrenkin (mas. 200-201) vetoavat siihen, että alkuperäinen rauniokiuas on koostunut pelkästä kuumennettavasta kivikasasta. Itämerensuomen *sakna- ja germaanin *stakka-sanojen semanttisen yhteyden Kallio (mas. 316) selittää viittaamalla mm. siihen, että samaa kantaa on myös suomen takka, jonka taustaksi selittyvät ruotsin murteiden samaa tarkoittavat stack(a/e) ja stäck. ${ }^{2}$

Itämerensuomen *sakna-sanalle on siis mahdollista olettaa tulisijaan viittaava merkitys jo lainanantajataholla. Myös nykymerkityksen 'sauna' Kallio katsoo yhdistyvän vaivatta sille olettamaansa aiempaan 'kiuas'-merkitykseen; hän huomauttaakin, että mitään muutakaan yleisitämerensuomalaista 'kiuas'-sanaa ei tunneta. Onkin mahdollista ajatella, että kiukaaseen viittaavat itämerensuomalaiset sanat ovat muotoutuneet nykyiselleen osin vasta sen jälkeen, kun aiempi sana vakiintui viittaamaan vain rakennuksiin, joissa kuumennettavat kivikasat sijaitsevat. Juuri *kivikasa - toisin kuin *kivikota - auttaa vaivatta ymmärtämään senkin, miksi kiuas-sanan tarkoitteita ovat vanhastaan olleet myös kivikasoista suurimmat, joihin nykyään viitataan yleensä yhdyssanalla hiidenkiuas ja myös mm. nimillä röykkiöhauta ja kiviröykkiö, ruotsiksi jättehög. Samalla saa selityksensä myös SMS:n (s.v.) Saloisista mainitsema esimerkki Siell_om pienijäki kiukaita (= vedenalaisia kivikoita, kareja) tuola syvälläki veellä. Nämä kiukaan merkitykset ovat epäilemättä toisasteisia, mutta nekin kertonevat siitä, että sanan merkityksen ytimenä on säilynyt ajatus kivikasasta.

Lopuksi on vielä paikallaan esittää myös semanttinen arvio *kivikota-hypoteesia mahdollisesti tukevista seikoista. Hypoteesia ei tiettävästi ole aiemmin arvioitu lainkaan, vaan se näkyy toistetun vuosikymmenestä toiseen sellaisenaan. Edes vaihtoehtoisten etymologioiden tarjoajat eivät vaikuta *kivikota-hypoteesia eksplisiittisesti arvostelleen, mutta on todettava, että sen uskottavuudesta ei ole mitään ilmeisiä merkkejä. Jaksossa 2.1 esitetty katsaus kiukaan historiaan ja sen nimityksiin muissa kielissä osoittaa, että hallitseva tekijä kiukaan nimeämisessä on sen raaka-aine, kivi. Sitä vastoin kiuasta ei kutsuta tiettävästi missään kivikodaksi, kivikasaksi kylläkin (vepsän küudug ja mokšan kevтаr (кевмар)).

Ajatus lähtömuodosta *kivikasa ei semanttisia perusteluja juuri kaipaisi, mutta *kivikota huomattavasti enemmän. Lindgrenin (1982) lainaetymologiaa arvostellessaan Itkonen $(1983,124)$ kyllä puolustaa perinteistä *kivikota-hypoteesia esittäen, että oletus "tuntuu luontevalta, varsinkin kun Räsänen on tukenut sitä myös semanttisin paralleelein”, mutta Räsäsen $(1947,354)$ argumentit

\footnotetext{
${ }^{2}$ Kaukaisempia paralleeleja kasan ja tulisijan yhteydestä Kallio (mp.) mainitsee myös islannista ja baltista sekä itämerensuomesta, jonka patsas voi virossa viitata mm. tulisijaan. LÄGLOS (s.v. sauna) tosin suhtautuu Kallion etymologiaan epäilevästi, mutta esimerkiksi Koivulehto (2007: 578) ei näe selityksessä ongelmaa.
} 
rajoittuvat juuri kiukaiden ja kivien yhteyteen venäjän kamenka-sanan kaltaisten paralleelien valossa; kotia tai niihin verrattavia käsitteitä Räsäsenkään esimerkistö ei sisällä. On totta, että kuvan 1 rauniokiuas voi muodoltaan muistuttaa jonkinlaista asumusta, mutta $k o t a$-sanaan viittaaminen tuntuu - edellä kuvailtujen äänteellisten ongelmien lisäksi - varsin kaukaa haetulta. Yhtä "kodinomaisia" ovat rakenteeltaan muutkin uunit, mutta uunien ja asumusten nimeämisessä on yleensä oleellisinta niiden funktio eikä muoto: uuneja ei tiettävästi missään luonnehdita esimerkiksi ’kivitaloiksi" sen enempää kuin esimerkiksi luukunomaisella sisääntuloaukolla varustettuja puutaloja "puu-uuneiksi". Monen nykysuomalaisen mielestä kota-sanaa kuvannee hyvin Kielitoimiston sanakirjan (s.v.) määritelmä 'yläpäästään yhdistettyjen pystyriukujen varaan rakennettu, taljoilla, tuohilla tms. katettu asumus; sen tapainen katteeton t. harva neliseinäinen hirsisuoja', mutta SMS:n tietojen mukaan sanalla on vanhastaan viitattu rakenteiltaan ja ulkoasuiltaan monenlaisiin alkeellisiin suojiin, katoksiin ja asumuksiin, karjakeittiöönkin, ja samasta kertovat myös sukukielten vastineet.

Lopuksi mainittakoon, että SMS:ssa (s.v.) on kyllä yksi poikkeuksellinen maininta kivikodasta, mutta ei saunaan viittaavassa merkityksessä: valkeen (= tulen) alla on (nuotiossa) kivikota 'kivistä rakennettu alusta' (Orivesi). Nykysuomessa kivikodiksi on nimetty vain jokunen kivistä rakennettu retkeilymaja, kun taas kiuasta on mitä tavallisinta kuvailla kivikasaksi niin kuin jo vanhastaan on tehty: Muun muassa SMS:n (s.v. kivikasa) Urjalan informantti on kertonut - jakson 2.1 kuvauksen mukaisesti - vanhoista savusaunoista, että niiss_oli kivikasa nurkassa. Mikäli kiuas halutaan kuitenkin edelleen yhdistää juuri kotaan, tämän näkemyksen kannattajien olisi viimeinkin pyrittävä esittämään myös semanttisia argumentteja käsityksensä tueksi. ${ }^{3}$

\section{Yhteenvetoa ja pohdintaa}

Yllä olen pyrkinyt perustelemaan mahdollisimman kattavasti käsitykseni, että suomalaisen kansankulttuurin omaleimaisimpaan ytimeen kuuluvan kiukaan nimitys on alkuperältään hämärtynyt yhdyssana *kivikasa eikä vakiintuneen, mutta puutteellisesti perustellun käsityksen

\footnotetext{
${ }^{3}$ Tämän artikkelin nimetön arvioija on ystävällisesti huomauttanut, että kivi-alkuisten yhdyssanojen lyhenemisestä puhuttaessa huomion ansaitsee myös Ganschow (1996), jonka mukaan järven ja samannimisen kunnan nimi Kyyjärvi Keski-Suomessa voitaisiin yhdistää naapurikunnan ja -järven Kivijärven nimeen. Vaikka Ganschow menee niinkin pitkälle, että hän päätyy palauttamaan koko kyy-sanan kivi-sanaan (vrt. esim. SSA s.v.), on merkillepantavaa, että yli 16 neliökilometrin laajuisen mutta silti keskisyvyydeltään vain 1,59 metrin syvyisen Kyyjärven nimeämisperusteena olisi varsin luonnollista pitää järven kyseenalaisen kyisyyden sijaan sen kivisyyttä.
} 
mukainen *kivikota. Sanan alkuperän tarkastelu antaa aihetta myös yleisempiin pohdintoihin suomen sanojen etymologisen tutkimuksen perinteistä, haasteista ja mahdollisuuksista.

Perusteellisimmat etymologiset sanakirjamme eivät tarkalleen ottaen esitä perinteistä *kivikotaselitystä varmana, mutta juuri tätä ne käytännössä tukevat. Vuosikymmeniä ainoan etymologisen sanakirjan asemassa toiminut SKES esittää vain tämän selityksen, joskin hieman etäännyttävin sanoin "sanan alkumuodoksi joskus ajateltu *kivikota". SSA puolestaan toteaa, että "lähtömuodoksi on oletettu usein *kivikota”, ja kannattaa selvästi juuri tätä selitystä. Viimeisimpien lausuntojen joukossa itämerensuomalainen kielikartasto ALFE (1: 172) esittää oletuksen lähes kiistattomana: "Vepsä (asut küudug, köuduk, kiiduk) näyttää osoittavan vielä selvemmin kuin muut kielet, että oletus ims kiuas-pesyeen palautumisesta asuun *kivikota on oikea (...)". Argumentti on itse asiassa hämmästyttävä, koska vepsän ja lyydin sanat näyttävät palautuvan sekä muodoltaan että merkitykseltään aivan toisenlaiseen muotoon, jonka lähin semanttinen vastine lännessä olisi pikemminkin *kivikasa eikä *kivikota.

On paikallaan kysyä, millä perustein *kivikota-hypoteesi on aikanaan esitetty ja myöhemmin vakiinnutettu. Yllä (jaksossa 2.2) mainittiin, että ensimmäisenä *kivikota > kiuas -selityksen vaikuttaa esittäneen Uuno Taavi Sirelius (1907, 128), joka suomalais-ugrilaisten alkuperäisiä asumuksia käsittelevässä tutkimuksessaan toteaa, että sana koostuu ilmiselvästi sanoista kivi ja kota. Kansatieteilijä Sirelius ei kuitenkaan profiloitunut ensisijaisesti kielentutkijaksi ja mahdollisesti tästä syystä hän on lisännyt oletuksensa tueksi alaviitteen, jossa kertoo kysyneensä Heikki Ojansuun mielipidettä moisesta etymologiasta. Sireliuksen mukaan Ojansuu on todennut selityksen äänteellisesti ongelmattomaksi. Edellä on käynyt ilmi, että *kivikota-selityksen äänteellisiä ongelmia eivät ole muutkaan sittemmin osoitelleet, mikä varmasti onkin vaikuttanut selityksen vakiintumiseen etenkin, kun etymologiset sanakirjat ovat samalla vaienneet kilpailevista selityksistä. Tässä yhteydessä on kuitenkin mielenkiintoista panna merkille, että muutama vuosi Sireliuksen etymologian jälkeen Ojansuu $(1913-1918,7)$ itse esitti Inkerin suomalaismurteisiin kuuluvan Ala-Laukaan murteen kiukaa-sanan taivutusta käsitellessään rekonstruktion " $<* k i u k a \delta a$, $?^{*} k i u k o \delta a ”$. Minimalistisuudessaankin tämän voi tulkita viittaavan siihen, että Ojansuulle jäi arvoitukseksi, miten tuon seudun - tai oikeammin koko Inkerin (ks. kartta 1) - murteiden

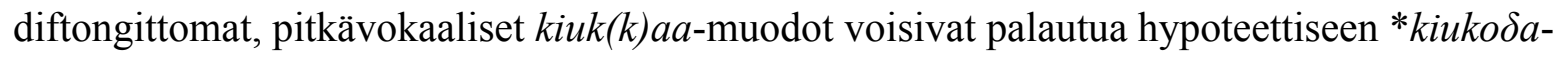
muotoon, jota *kivikota-hypoteesi edellyttäisi. Toisin sanoen *kivikota-hypoteesin alkuperäisen esittäjän tukijakseen mainitsema äännehistorian asiantuntija päätyi omassa tuotannossaan pikemminkin ihmettelemään kuin tukemaan *kivikota-selitystä. Tähän ei sittemmin näy kiinnitetyn huomiota. 
Perusteiltaan kyseenalaisen ja *kivikasa-oletukselle oikeastaan joka suhteessa häviävän *kivikotahypoteesin menestyksen voi selittää lähinnä sillä, että muitakaan varteenotettavia selitysmalleja ei ole ollut tarjolla ja alkuaan varsin kepein perustein etymologiseen kirjallisuuteen päässyttä hypoteesia ei ole sen koommin juuri pysähdytty kyseenalaistamaan. Vaikuttaa siltä, että Lindforsin (1893) varhainen *kivikasa-ehdotus on jäänyt alusta alkaen unohduksiin. Kun samantyyppinen rekonstruktio nousi toistamiseen esiin sata vuotta myöhemmin, Ritterin (1993) esittämä *kiukasaon niin ikään ollut helppo jättää omaan arvoonsa, koska etymologiseksi selitykseksi ei riitä pelkkä tokaisu, vaan esitetty etymologia pitäisi perustella. Puheena olevan *kivikasa-oletuksen osalta tämä olisi ollut varsin helppoa, mutta argumentoinnin täydellisesti puuttuessa pelkät irralliset huomautukset (Lindfors 1893, Ritter 1993, NSES) ovat metodologisesti eräänlaisia maallikkoetymologioita: ei riitä, että etymologioidut sanat vaikuttavat joltakin.

Yhdyssanan *kivikasa kiteytyminen läpinäkymättömiksi sanoiksi kuten kiuas, kiukaa ja kiukoa edustaa etymologian periaatteiden kannalta mielenkiintoista, mutta fennistiikassa varsin vähälle huomiolle jäänyttä ilmiötä. Tämänkaltaisten yhdyssanoihin palautettujen etymologioiden osuus suomen sanaston tutkimuksessa on häviävän pieni verrattuna siihen, kuinka keskeisiä yhdyssanat ovat varmasti jo nykysuomea edeltäneissä kielimuodoissa olleet. Aivan tuntemattomia yhdyssanoista tai sanaliitoista kiteytyneet sanat eivät suomessa kuitenkaan ole. Esimerkkeinä samaan tapaan selitetyistä sanoista Häkkinen (1990, 149, 157-158) mainitsee muun muassa sanat anoppi, kainalo, sentään ja vanhurskas. Vanhinta tämänkaltaista sanastokerrostumaa edustaa anoppi, jonka voi katsoa koostuvan kantauralin anoppia ja appea merkinneistä sanoista (Janhunen 1981, 227-228; SSA s.v.). Suomen nykykielen yhdyssanojen produktiivisuutta vastikään laajasti kuvannut Tyysteri (2015, 29-30) jättää vanhojen, hämärtyneiden yhdyssanojen tarkastelun tutkimuksensa ulkopuolelle, mutta toteaa ilmiön suomessa hyvin harvinaiseksi.

Suomeen verrattuna melko paljon hämärtyneitä yhdyssanoja näyttäisi kuitenkin esiintyvän virossa. Esimerkiksi viron etymologisen sanakirjan (EES) toimittaneet Metsmägi ym. (2013, 320) mainitsevat yhdyssanalähtöisiksi sanat aasta 'vuosi', aituma aitäh 'kiitos', külimit '(kylvö)vakka', künnap 'kynäjalava; jänne', millal 'milloin', nagu 'kuten', ning 'sekä', nõnda 'niin', paharet 'paholainen', pilgar 'ilonpito', praegu 'paraikaa', teistre 'naapurin', tänavu 'tänä vuonna', uibu 'omenapuu', veski 'mylly' ja ööbik'satakieli'. On toki oma kysymyksensä, kuinka perusteellisesti edellä mainitut sanat on etymologioitu (etymologioista ks. etenkin EES), mutta viron ja suomen erot voivat johtua jossakin määrin erilaisista tutkimusperinteistä eivätkä välttämättä siitä, että yhdyssanojen kiteytyminen suomessa olisi harvinaisempaa. Paikannimistön osalta 
yhdysnimien hämärtyminen on kyllä hyvin tunnettu tosiasia fennistiikassakin (esim. Rahkonen 2013).

Vanhoiksi yhdyssanoiksi selittyvien sanojen ja nimien etymologiointi on kuitenkin paljon epävarmempaa kuin tavallisempien etymologisten selitysten puntarointi: Olipa kyse vanhasta perussanastosta, jonka vastineet löytyvät kaukaisistakin sukukielistä (esim. uralilainen kivi) tai uudemmista lainasanoista (esim. germaanista alkuperää oleva kasa), etymologisten selitysten nimenomaisena tavoitteena on osoittaa yhdistettävien sanojen suhteet äännehistoriallisesti säännöllisiksi ja odotuksenmukaisiksi. Mitä paremmin tämä ehto täyttyy, sitä uskottavampi selitys on. Hämärtyneet yhdyssanat sen sijaan ovat määritelmällisesti hämäriä, arvaamattomia: suomen kielihistoria ei tunne äännelakeja, joiden mukaan kiuas tai edes vartalo kiukaha- olisi selitettävissä *kivikasa-yhdyssanan odotuksenmukaiseksi perilliseksi. Ruotsin bastu olisi "oikeasti” badstuga. Samoin viron veski 'mylly' vaikuttaa olevan sinänsä aivan epä-äännelaillinen kiteytymä oletetusta alkumuodosta *vesikivi. Jopa ersän samaa tarkoittava v́édǵev (ведьгев) soinnillisine ǵ-äänteineen on hieman odotuksenvastainen muoto sanojen v́ed́ 'vesi' ja ḱev 'kivi' yhteen lankeamisesta. Toisin sanoen odotuksenmukaisia, äännelaillisia muotoja ovat vain edelleen läpinäkyvät yhdyssanat kivikasa, badstuga, vesikivi ja v́éd-ḱev. Myöhemmät kehittymät kiuas ja veski-joiden pohjalta voidaan luoda jopa uudet yhdyssanat kiuaskivi, kiuaskivikasa, bastubad, bastustuga, vesiveski 'vesimylly' ja veskikivi 'myllynkivi' - ovat kerta kaikkiaan ennalta arvaamattomia ja muistuttavat tässä suhteessa affiksien morfologisoitumista entisistä itsenäisistä sanoista: suomen isän kanssa ja vanhan viron isa kaas vastaavat kyllä toisiaan varsin säännönmukaisesti, mutta nykyviron komitatiivi isaga on äännehistoriallisesti odotuksenvastainen - odotuksenmukaisesti on säilynyt vain adverbi $k a$ (esim. isa $k a$ 'isä kanssa').

Täydellisyyden vuoksi on todettava, että etymologisesti läpinäkymättömiä yhdyssanoja voi syntyä myös säännöllisen äännekehityksen tuloksena. Kuvaava esimerkki on riimunvartta, hevosen talutusnarua merkitsevä marhaminta, jonka alkuosan marha- alkuperäksi on selitetty kantagermaanin *marhaz 'hevonen' ja loppuosan -minta alkuperäksi saman tai samantyyppisen kielimuodon *minpla 'suitset' (LÄGLOS, SSA s.v.). Yhdyssanaa *marha-minpla ei germaaniselta taholta tunneta, joten periaatteessa on mahdollista olettaa, että marhaminta on alkuaan itämerensuomessa muodostettu ja sinänsä säännönmukaisena säilynyt yhdyssana, joka on hämärtynyt alkuperäisten komponenttien, lainasanojen *marha ja *minta kadotessa.

Yhdyssanojen runsaus sekä yhdyssanojen hämärtymisen luonnollisuus yhdessä tällaisen kehityksen epäsäännöllisyyden kanssa tarjoavat etymologialle mielenkiintoisia, mutta vaarallisia 
mahdollisuuksia. Koska yhdyssanojen opaakkiutumisessa on aina kyse poikkeuksellisista yksittäistapauksista, etenkin kielen varhaishistoriaan uusia vastaavia etymologioita voisi periaatteessa keksiä hyvinkin vapaasti. Yksi verrattain rohkea, mutta vaikeasti mitätöitävissä oleva sananselitys on Viitson (2012, 193-196) pyrkimys selittää uralilaiskielissä varsin monenlaisia metalleja ja metalliseoksia merkitsevän vaski-sanan kantamuoto eräänlaiseksi lyhentymäksi muodosta *vaśakive, jonka merkitys olisi alkuaan ollut ikään kuin "vasarakivi" - kiviaines tai kiveksi hahmotettu mineraali, josta on saatu muun muassa vasaroita. Samassa hengessä on mahdollista esittää, että suomen järvi-sanalle ja sen sukukielisille vastineille esitetyt balttilaisetymologiat (esim. Nuutinen 1989) voisi korvata oletus kivettyneestä yhdyssanasta, jonka määriteosana olisi ollut suomalais-permiläinen *järs 'ympyrä, kehä; kehämäinen, rajattu' (ks. UEW s.v.) ja perusosana ikivanha *weti 'vesi'. Kehitykselle *järsweti >> järve-tarjoutuisivat jopa typologisiksi paralleeleiksi esimerkiksi mordvalaiskielten ineved' 'meri; Volga' ('suuri' + 'vesi'; "enävesi") ja semantiikan puolesta erityisen hyvin tok pisinin raunwara 'järvi' << englannin round + water (tok pisinin bikwara 'pääjoki' puolestaan rinnastuu mordvan Volgaankin viittaavaan ińeved́-sanaan). ${ }^{4}$

Vastaavia sananselityksiä olisi toki mahdollista esittää enemmänkin, mutta ne ovat lähtökohtaisesti vaarallisia - tavallisista etymologisista selityksistä poiketen ne suorastaan edellyttävät epäsäännöllisiä muutoksia. Yllä esitetyt vaskea ja järveä koskevat pohdinnat tuovatkin mieleen eksentrikko Sigurd Wettenhovi-Aspan legendaariset sananselitykset (Pitkälä 2010), joiden voinee olettaa hillinneen suomalaisten etymologien intoa maltillisiinkin yhdyssanaetymologioihin. Suomen kiuas, karjalan kiukua ja vaikkapa viron veski vaikuttavat kuitenkin epäsäännöllisyydessäänkin niin yksiselitteisiltä, että tämänkaltaisten etymologisesti suhteellisen läpinäkyvien nuorten sanojen maltillinen tarkastelu voi jatkossa auttaa tunnistamaan myös kauempaa muinaisuudesta periytyviä entisiä yhdyssanoja.

\footnotetext{
${ }^{4}$ Spekulaation *järsweti >> järvi leikillisyydestä huolimatta on syytä huomata, että vallalla oleva Nuutisen (1989) esittämä balttilaisetymologia (vrt. liettuan jáura 'suo, rämeikkö’) on jättänyt jälkeensä kiistanalaisia ja kilpailevia tulkintoja tämän merkitykseltäänkin muuttuneen sanan äänneasujen enemmän tai vähemmän sporadisista muutoksista. Itämerensuomen, saamen (pohjoissaamen jávri), mordvan (ersän eŕke) ja marin (itämarin jer) sanojen yhteistä edeltäjää on rekonstruoitu muodoiksi *järvä (NSES) ja *jävrä (Sammallahti 1998, 249), joten jo itämerensuomen ja saamen sanojen yhteensovittaminen edellyttää konsonanttiyhtymän metateesiä ja vartalovokaalin muuttumista yhdessä tai useammassa kielimuodossa.
} 
Lähteet

AHLQVist, AUGUST 1866: Om Finska språkets kulturord. Ett linguistiskt bidrag till Finnarnes äldsta kulturhistoria. Suomi II: 6, 67-114.

AHLQVIST, August 1877: Suomen kielen rakennus. Vertaavia kieliopillisia tutkimuksia. I.

Nominien synty ja taivutus. Suomalainen runo-oppi. Suomalaisen Kirjallisuuden Seura, Helsinki.

ALFE = Atlas Linguarum Fennicarum. Itämerensuomalainen kielikartasto 1. Suomalaisen

Kirjallisuuden Seuran toimituksia 800, Kotimaisten kielten tutkimuskeskuksen julkaisuja 118.

Suomalaisen Kirjallisuuden Seura - Kotimaisten kielten tutkimuskeskus, Helsinki, 2004.

EES = METSMÄgI, IRIS - SEDRIK, MEELI - SOOSAAR, SVEN-ERIK (toim.) 2012: Eesti

etümoloogiasõnaraamat. Eesti Keele Sihtasutus, Tallinn.

GANSCHOW, GERHARD 1996: 'Stein' und 'Sumpf' in finnischen Gewässernamen. Heikki Leskinen Sándor Maticsák - Tõnu Seilenthal (toim.): Congressus Octavus Internationalis Fenno-

Ugristarum. Jyväskylä 10.-15.8. 1995. Pars V. Sessiones sectionum. Lexicologia \& Onomastica, 228-230. Jyväskylä.

HelAmAA, ERKKI 1999: Kiuas - saunan sydän. Karisto, Hämeenlinna.

HelamaA, ERKKi 2000: Saunan ja kiukaan historiaa. Juha Pentikäinen (toim.): Löylyn henki.

Kolmen mantereen kylvyt: inipi, furo, sauna, 114-122. Rakennustieto, Helsinki.

HÄKKINEN, KAISA 1990: Mistä sanat tulevat. Suomalaista etymologiaa. Tietolipas 117.

Suomalaisen Kirjallisuuden Seura, Helsinki.

ITKONEN, TERHO 1983: Sovijärven ystävät äänessä. Virittäjä 87, 122-126.

JANHUNEN, JUHA 1981: Uralilaisen kantakielen sanastosta. Suomalais-Ugrilaisen Seuran Aikakauskirja 77, 219-274.

KALliO, Petri 2008: The etymology of Finnish sauna 'sauna'. Kees Dekker - Alasdair MacDonald - Hermann Niebaum (toim.): Northern voices. Essays on Old Germanic and related topics offered to professor Tette Hofstra, 313-319. Mediaevalia Groningana New Series 11. Peeters, Leuven - Paris - Dudley, MA.

KeTtUnen, LAURI 1922: Lõunavepsa häälik-ajalugu. II. Vokaalid. Acta et Commentationes Universitatis Dorpatensis B III, 4. Tartu.

Kettunen, Lauri 1940: Suomen murteet III A. Murrekartasto. Suomalaisen Kirjallisuuden Seura, Helsinki.

Kielitoimiston sanakirja. 2016. Kotimaisten kielten keskus, Helsinki. URN:NBN:fi:kotus-201433, ISSN 2343-1466. Verkkojulkaisu HTML. Päivitettävä julkaisu. Päivitetty 29.2.2016 [viitattu 9.4.2016]. 
KKS = VIRTARANTA, PERTTI - KOPONEN, RAIJA (päätoim.) 1968-2005: Karjalan kielen sanakirja I-VI. Lexica Societatis Fenno-Ugricae XVI:1-6. Suomalais-Ugrilainen Seura, Helsinki.

Koivulehto, Jorma 2007: Auf der Suche nach germanischen Elementen im heutigen Wortschatz des Ostseefinnischen und Saamischen. Neuphilologische Mitteilungen 108, 577-590.

LINDFORS, A. E. 1893: Tutkimus Heinolan murteesta. Suomi III: 6.

LINDGREN, KAJ B. 1982: Ist der Saunaofen kiuas germanisch? Versuch einer phonologischen Etymologie. Voces amicorum Sovijärvi. In honorem Antti Sovijärvi septuagesimum annum agentis die XXII mensis aprilis anno MCMLXXXII, 199-207. Suomalais-Ugrilaisen Seuran Toimituksia 181. Suomalais-Ugrilainen Seura, Helsinki.

LMS = KUJOLA, JUHA 1944: Lyydiläismurteiden sanakirja . Lexica Societatis Fenno-Ugricae IX. Suomalais-Ugrilainen Seura, Helsinki.

LÄGLOS = KYlstrA, A. D. - HAhMO, SirKKA-LiISA - HofSTRA, TeTtE - NiKKILÄ, Osmo 19912012: Lexikon der älteren germanischen Lehnwörter in den ostseefinnischen Sprachen I-III. Rodopi, Amsterdam.

METSMÄGI, IRIS - SEDRIK, MEELI - SOOSAAR, SVEN-ERIK 2013: Eesti kirjakeele tüvevara päritolu arvudes. Keel ja Kirjandus 56, 313-332.

MW = H. Paasonens Mordwinisches Wörterbuch. Zusammengestellt von Kaino Heikkilä. Bearbeitet und herausgegeben von Martti Kahla. Lexica Societatis Fenno-Ugricae XXIII. Suomalais-Ugrilainen Seura, Helsinki 1990-1999.

NSES = HÄKKINEN, KAISA 2004: Nykysuomen etymologinen sanakirja. WSOY, Helsinki.

NuUtinEN, OlLi 1989: Järvi - balttilainen laina. Virittäjä 93, 497-503.

OJANSUU, HEIKKI 1913-1918: Äännehistoriallista. Suomalais-Ugrilaisen Seuran Aikakauskirja $30,17,1-18$.

PentikäInen, JuHA 2000: Löylyn henki. Juha Pentikäinen (toim.): Löylyn henki. Kolmen mantereen kylvyt: inipi, furo, sauna, 102-113. Rakennustieto, Helsinki.

PitKäLÄ, PeKKA 2010: Pyramidit, pyhät raamit. Sigurd Wettenhovi-Aspan (1870-1946) näkemykset suomen kielestä ja suomalaisten historiasta. Pro gradu -tutkielma. Historian, kulttuurin ja taiteiden tutkimuksen laitos, Turun yliopisto.

RAHKONEN, PAULI 2013: Suomen etymologisesti läpinäkymätöntä vesistönimistöä. Virittäjä 117, 543.

RAPOLA, MARTTI 1933: Suomen kirjakielen historia pääpiirteittäin. I. Vanhan kirjasuomen kirjoitus- ja äänneasun kehitys. Suomalaisen Kirjallisuuden Seuran toimituksia 197. Suomalaisen Kirjallisuuden Seura, Helsinki.

RAPOLA, MARTTI 1966: Suomen kielen äännehistorian luennot. Suomalaisen Kirjallisuuden Seuran toimituksia 283. Suomalaisen Kirjallisuuden Seura, Helsinki. 
RitTer, RALF-Peter 1993: Studien zu den ältesten germanischen Entlehnungen im

Ostseefinnischen. Opuscula Fenno-Ugrica Gottingensia 5. Peter Lang, Frankfurt am Main.

RÄSÄNEN, MARTTI 1947: Etymologisia lisiä 4-6. Virittäjä 51, 354-357.

Sammallahti, PekKa 1998: The Saami languages. An introduction. Davvi Girji, Kárášjohka.

SIRELIUS, U. T. 1907: Über die primitiven wohnungen der finnischen und ob-ugrischen völker.

Finnisch-Ugrische Forschungen 7, 55-128.

SKES = TOIVONEN, Y. H. - ITKONEN, ERKKI - JoKi, AUlis J. - PELTOLA, ReINO 1955-1981:

Suomen kielen etymologinen sanakirja I-VII. Lexica Societatis Fenno-Ugricae XII:1-7.

Suomalais-Ugrilainen Seura, Helsinki.

SMS = Suomen murteiden sanakirja I-. Kotimaisten kielen tutkimuskeskuksen julkaisuja 36.

Kotimaisten kielten tutkimuskeskus - Valtion painatuskeskus, Helsinki, 1985-.

SSA = ITKONEN, ERKKI - KULONEN, UlLA-MAiJA (toim.) 1992-2000: Suomen sanojen alkuperä.

Etymologinen sanakirja I-III. Suomalaisen Kirjallisuuden Seuran toimituksia 556. Kotimaisten

kielten tutkimuskeskuksen julkaisuja 62. Suomalaisen Kirjallisuuden Seura - Kotimaisten

kielten tutkimuskeskus, Helsinki.

SVJa = ЗАЙЦЕВА, М. И. - МуЛЛОНЕН, М. И. 1972: Словарь вепсского языка. Наука, Ленинград.

TSYPANOV 2013 = ЦыПАнов, Е. А.: Названия бани в финно-угорских языках. Финно-угорский мир 2013: 2, 82-85.

TYYSTERI, LAURA 2015: Aamiaiskahvilasta ötökkätarjontaan. Suomen kirjoitetun yleiskielen morfosyntaktisten yhdyssanarakenteiden produktiivisuus. Annales Universitatis Turkuensis. C:

Scripta Lingua Fennica Edita 408. Turun yliopisto, Turku.

UEW = RÉDEI, KÁROLY (toim.) 1988-1991: Uralisches etymologisches Wörterbuch I-III. Unter

Mitarbeit von Marianne Bakró-Nagy, Sándor Csúcs, István Erdély, László Honti, Éva Korenchy, K. Sal und Edit Vértes. Otto Harrassowitz, Wiesbaden.

VIITSO, TIIT-REIN 2012: Early metallurgy in language: The history of metal names in Finnic. Riho

Grünthal - Petri Kallio (toim.): A linguistic map of prehistoric Northern Europe, 185-200.

Suomalais-Ugrilaisen Seuran Toimituksia 266. Suomalais-Ugrilainen Seura, Helsinki.

VILKUNA, KUSTAA 1972: Sauna-sana ja alkuperäisin sauna. Sauna 1972: 2, 3-5.

ÄIMÄ, F. 1921: Lisänen ahrain sanan etymologiaan. Virittäjä 25, 63-71. 
JUSSI YLIKOSKI: Finnish kiuas, Karelian kiukua 'sauna stove' and remarks on the Finnic etymological tradition

The article revisits and reevaluates the origins of the North Finnic word for 'sauna stove'. According to the received view - originally presented in Uuno Taavi Sirelius' (1907) study on dwellings of Uralic peoples - Finnish kiuas with variants such as kiukaa, kiukoa and kiukas, Karelian kiuku(v)a and kiugua as well as Ingrian kiukā and Vote tšiukas originate in the Finnic (Finnish) compound noun *kivikota made up of kivi 'stone' and kota 'hut; shelter'. Further, Lude kiudug and Veps küudug 'sauna stove' have also been related to the above-mentioned words.

Critical reevaluation of the received view makes it evident that the *kivikota 'stone hut' explanation is quite problematic both from a morphological and semantic point of view. From the morphological perspective, the *kivikota hypothesis presupposes a large array of sound changes and analogical shifts that nevertheless account only for a fraction of actual variants of the word without severely conflicting with a number of well-known sound changes in North Finnic. From the semantic perspective, relation of sauna stoves - originally consisting of heaps of stones - to the primary referents of kota 'hut; shelter' has never been explained.

As the classical "stone hut" explanation must be considered unsatisfying, there are good reasons to reevaluate a nearly forgotten conjecture put forward by A. E. Lindfors (1893) who proposed that kiuas might originate in the compound noun *kivikasa, consisting of kivi 'stone' and kasa 'pile; heap'. As it turns out, the *kivikasa hypothesis accounts for most of the morphological variants as well as the semantic functions of Finnish kiuas, Karelian kiukua and their obvious cognates in Ingrian and Vote. Although the initial step in the emergence of a new noun for 'sauna stove' has required a sporadic and irregular change from the compound *kivikasa 'heap of stones' towards the less transparent *kiukas (a), the subsequent development à la *kivikasa (nominative) : *kivikasan (genitive) $>>$ present-day Finnish kiu(k)as : kiuka(h)an etc. must be regarded more or less regular. As for the semantics, a reconstructed meaning 'heap of stones' for 'sauna stove' is paralleled by analogical compounds like Moksha kevmar (кевмар) 'sauna stove; heap of stones' (from kev 'stone' and mar 'heap') and is thus far more plausible than the received view about the "stone hut" origins of kiuas.

The paper concludes that the "stone hut" theory on the origins of the word for the core element of Finnic sauna must be abandoned as invalid and unproven, whereas the compound *kivikasa 'heap of stones' provides a nearly perfect explanation. The main reason for the popularity of the *kivikota 
theory appears to be the fact that Sirelius' premature hypothesis has been gradually canonized in the absence of any serious attempts to question its plausibility or to provide alternative, morphologically and semantically sound explanations for the designation of the very core of the Finnic sauna culture.

Jussi Ylikoski

Institutt for språk og kultur

HSL-Fakultet

UiT Norges arktiske universitet

NO-9037 Tromsø 